\title{
高層集合住宅における加圧防煙 PERFORMANCE EXAMINATION TEST システムの性能確認実験 OF PRESSURIZED SMOKE CONTROL SYSTEM FOR A HIGH-RISE APARTMENT BUILDING
}

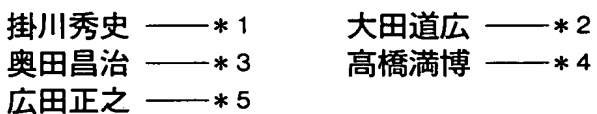

キーワード

加圧防煙システム, 高層集合住宅, 性能確認実験, 有奻開口面皘

Keywords :

Pressurized smoke control system, High-rise apartment building, Performance examination test, Effective flow area

\author{
Shuji KAKEGAWA $-* 1$ \\ Masaharu OKUDA -*3 \\ Masayuki HIROTA $-* 5$
}

Michihiro OTA $-* 2$
Mitsuhiro TAKAHASH $-* 4$

A pressurized smoke control system was employed in the 25 stories' high-rise apartment building named "Akasaka Tameike Tower." We have conducted a performance examination test of the system. From the results of the test, it was confirmed that: 1) the pressure differences at the evacuation routes agreed with the requirements for smoke prevention; and 2) door opening force in operating the system was low enough for the children to open the doors. Furthermore, effective flow areas of some architectural components, such as doors and pressure adjusting openings, were measured and design data for simulating the pressure difference of the system were collected.

\section{1.はじめに}

火災時の煙制御方式の一つとして, 高層事務所ビルを中心として, 加圧防煙システムの適用事例が増加している。同方式は，避難経路 となる廊下，付室等の安全区画に新鮮空気を給気し，火災室との間 に圧力差を与えることで，避難路や堅穴区画への漏煙を防ぐことを 目的としている。同方式の主な特長のひとつは, 従来の排煙設備と 比較して, 長時間避難路の安全性を確保できるため, 在館者の安全 性を高めることができることである。

一方，近年，都心部を中心として高層集合住宅が増加しているか， 高層集合住宅は，平面計画上，廊下が外気に直接面しない中廊下型 のプランを採用する事例が多く，火災時に避難路である中廊下の女 全性をいかに確保するかは火災安全計画上重要な課題である。

こうしたことから，筆者らは、こうした課題を解決するためのひ とつの方法として，事務所と中廊下型集合住宅が複合した高層建築 物に加圧防煙システムを採用し，実建物を対象とした加圧防煙シス テムの性能確認試験を実施した。

\section{2. 研究の目的}

従来加圧防煙システムは，高層事務所ビルを中心として適用がさ れており，集合住宅における適用例はほとんどみられない。

集合住宅は, 用途の特性上, 就寝を伴いかつ各住戸が区画されて いるため, 火災の覚知および避難開始が遅れる可能性がある。また， 高跲者や児童等, 運動能力の劣る人々が使用することが想定される。 このように，集合住宅では，火災時に事務所とは異なる避難のシナ リオが想定されることからこうしたシナリオに対応したシステム
の圧力制御による遮煙性能を把旺しておく必要がある。さらに、防 災計画上は，避難が遅れた場合でも加圧防煙システム起動時に贸の 開閉等で避難上支障が生じない計画とすることが重要である。

また，加圧防煙システムの設計の観点からは，建物部位毎の隙間 開口面積を把握することは，圧力変動の予測を行う上で重要となる。 集合住宅では，住戸や中廊下周辺に換気等のための配管が多く敷設 されており，事務所とは異なる隙間特性を有すると考えられる。

以上より，本研究では，加圧防煙システムを適用した集合住宅を 対象として，システムの性能確認実験および建物部位の隙間有効開 口面積の測定を行い，以下の点を明らかにすることを目的とする。

・集合住宅で想定される各火災シナリオにおける加圧防煙システム の圧力制御による遮煙性能

・システム起動時の圧力調整機構による屝開閉障害の防止効果

・住戸や廊下迴りを中心とした集合住宅の主要な部位の隙間有効開 口面積

\section{3. 対象建物の建築計画と加圧防喓システムの概要 \\ 3.1 建築計画の概要}

加圧防煙システムを適用した建物（赤坂溜池タワー）の概要を表 1 に, 住宅階の基淮階平面図を図 1 に示寸。低層階（2１3 階）は, 片側コア形式の事務所, 高層階（14２5 階）は, 中廊下を有するセ ンターコア形式の共同住宅（各階 12 戸，25階のみ 6 戸) から構成 されている。事務所階用エレベーター（6 基）は，地下 1 階から地 上 13 階に，住宅用エレベーター（2 基）は，地下 1 階および 1 階と 地上 14 階から 25 階の各階に連絡している。

\footnotetext{
*1 清水建設(侏技術研究所 副主任研究貝 - 博士 (工学)

（テ135-8530 東京都江東区越中島3-4-17)

*2 清水建設件)設計本部 グループ長

*3 清水建設㑣設呠部 副部長

*4 清水建設倠)設計本部

*5 清水建設㨆技術研究所主任研究貝
} 
表 1. 赤坂溜池タワー建物概要

\begin{tabular}{|c|c|c|}
\hline 建設地 & 東京都港区 & \\
\hline 建物用途 & $\begin{array}{l}\text { 事務所, 共同住宅 } \\
\text { 地下 } 2 \text { 階：機械室・駐車場 } \\
\text { 地下 } 1 \text { 階：駐車場 } \\
1 \text { 階 } \quad \text { : 店舗・エントランス }\end{array}$ & $\begin{array}{l}\text { 2〜13 階: 事務所 } \\
\text { 14〜25 階：共同住宅 }\end{array}$ \\
\hline 延べ床面積 & $47,758 \mathrm{~m}^{2}$ & \\
\hline 基準階面積 & 事務所階 : $1,676 \mathrm{~m}^{2}$ & 皆: $1,357 \mathrm{~m}^{2}$ \\
\hline 階数・高さ & 地下 2 階, 地上 25 階，塔屋 2 階 & 建物高さ $99.8 \mathrm{~m}$ \\
\hline 構造種別 & 地下 SRC 造, 地上 $S$ 造 & \\
\hline
\end{tabular}

表 2. 加圧防煙システムの作動シーケンス（住宅階）

\begin{tabular}{|c|c|c|c|c|c|}
\hline & \multirow[b]{2}{*}{ 設計仕様 } & \multirow{2}{*}{ 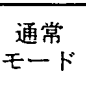 } & \multicolumn{2}{|c|}{ 漏煙モード } \\
\hline & & & & 排煙作動 & $\begin{array}{c}\text { 排煙 } \\
\text { 不作動 }\end{array}$ \\
\hline 給 & 付室給気ファン & $13,000 \mathrm{~m}^{3} / \mathrm{h} \times 2$ 系統 & 作動 & 作動 & 作動 \\
\hline 排 & 乗用エレベーター給気フアン & $30,000 \mathrm{~m}^{3} / \mathrm{h} \times 1$ 系統 & 作動 & 作動 & 作動 \\
\hline 気 & 廊下排煙ファン & $6,000 \mathrm{~m}^{3} / \mathrm{h} \times 2$ 系統 & 停止 & 作動 & 停止 \\
\hline 罪 & 付室防火戸 & $1.8 \mathrm{~m} \times 2.28 \mathrm{~m}$ & 開放 & 閉鎖** & 閉鎖** \\
\hline 等 & 圧力調整ガラリ & $1.0 \mathrm{~m} \times 2.25 \mathrm{~m}$ & 開放 & 開放 & 開放 \\
\hline
\end{tabular}

* 付室圧力調整屝は，開放のまま

特別避難階段付室は, 煙感知器連動の防火戸 2 箇所で区画されて おり，平常時は中廊下と一体の空間となっている。付室と非常用エ レベーター乗降ロビーは，防火戸を介して別の空間となっており， 在館者の避難経路と消防活動拠点とが平面上明確に分離されている。 但し, 付室と非常用エレベーター乗降ロビーは，天井裹に設置され たバイパス開口（面積約 $0.5 \mathrm{~m}^{2}$ ) を介して，加圧防煙上は連結され ており，一体の防火区画を構成している。

住宅階の各住戸，廊下には，スプリンクラー設備が設置されてい る。また，床面積が $100 \mathrm{~m}^{2}$ を超える住戸は，キッチンを単独で防火 区画し，住戸内での延焼払大を防止するとともに，住戸内の居室か ら中廊下へ至る安全な避難経路を確保している。

屋外バルコニーは, 外壁 4 面に 1 箇所ずつ設けられており, バル コニーを経由して，隣接する住戸人避難できる計画となっている。

\section{2 加圧防煙システムの概要}

住宅階の加圧防煙システムの構成を図 2 に, システムの作動シー ケンスを表 2 に示す。当システムは，火災時に火災階の非常用エレ ベーター乗降ロビー，付室，乗用エレベーターシャフトに加圧給気 し，廊下および乗用エレベーターシャフトを間接的に加圧すること により，火災階および非火災階の避難経路への煙伝播を防止する。

本計画では，中廊下の安全性を確保することが避難安全上重要と なることから，排煙設備の作動信頼性を考慮し，中廊下に独立した 2 系統の機械排煙設備を設けている。これにより，万が一出火住戸 から中廊下に漏煙した場合においても，火災階の安全な避難経路を 確保するとともに，付室と中廊下間，乗用エレベーターと中廊下間 で遮煙に必要となる圧力差を確保し，エレベーターシャフト等の堅 穴区画を介した非火災階への煙伝播防止を図っている。

一方, 集合住宅では，就寝時等に避難の開始が達れる可能性があ ることから，避難時の扉開閉障害を防止することが重要な課題とな る。このため本システムでは，住戸，中廊下，付室各々に下記の圧 力調整機構を設け，住戸屝，付室屝の開閉障害防止を図っている。

（1）住戸圧力調整口：各住戸の玄関脇側壁の床面近傍に,メータボ ックスと玄関を結ぶ圧力調整口（0.15申，0.3m の丸管）を設置 する。開口は常時開放されており，延芜执大防止のため，区画 貫通部に防火ダンパーを併設している。

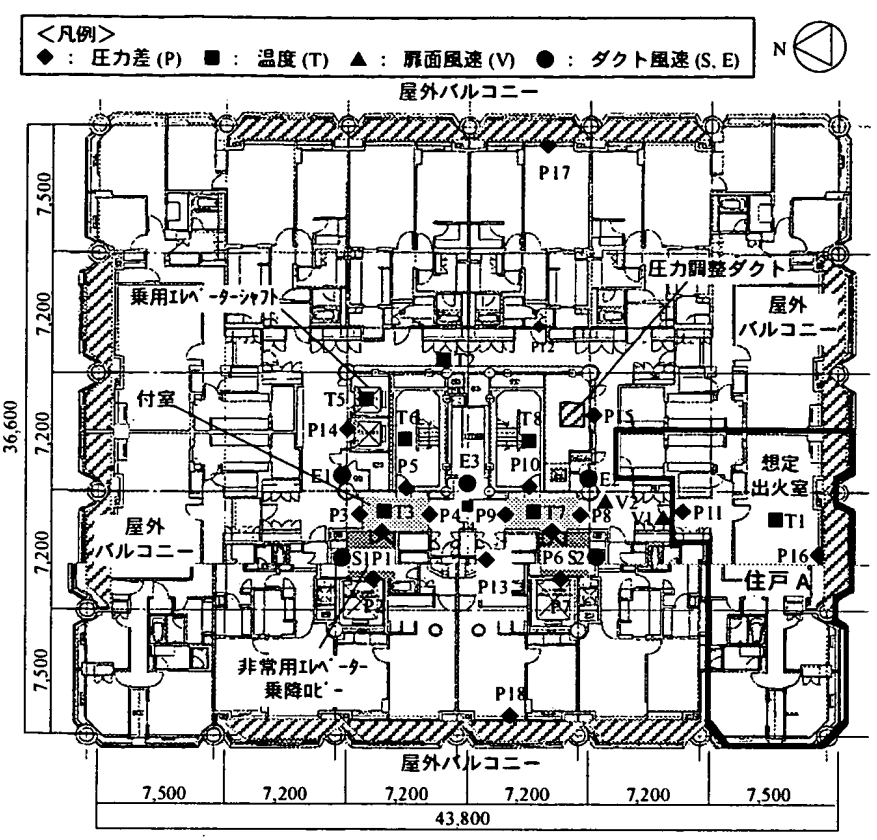

図 1. 住宅階基準階平面図と計測点位置

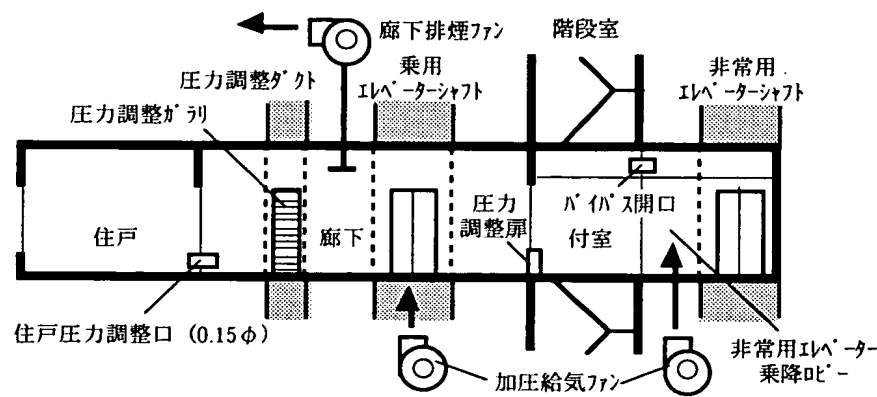

図 2. 加圧防煙システムの構成（住宅階）

（2）中廊下圧力調整ガラリ：住宅階の中廊下に，屋上階で外気に開 放された竪ダクト $(1.5 \mathrm{~m} \times 0.5 \mathrm{~m})$ に慗がる圧力調整用ガラリ $(1.0 \mathrm{~m}$ $\times 2.25 \mathrm{~m}$ ）を設置する（常時閉鎖の防火ダンパー併設）。付室加 圧ファンの起動に連動して，火災階の防火ダンパーを開放する。

(3) 付室圧力調整扉 : 乗用エレベーターホール側の付室防火戸を上 下 2 段（屝高さ：上段 $1.98 \mathrm{~m}$ ，下段 $0.3 \mathrm{~m}$ ）の構成とし，下段の 扉を, 熱感知器連動閉鎖式の圧力調整扉とする。

当建物は, 事務所と集合住宅の複合用途建物であるため, 防災セ シターでは 24 時間有人管理を行なっている[注 1]。このため, 加圧 防煙システムは, 火災階付室の起動ボタン操作または防災センター からの遠隔操作により起動させることを基本としている。

住宅階におけるシステムの作動シーケンスを以下に記す。

A. 通常モード：火災階付室の起動ボタン操作または防災センター からの遠隔操作により，非常用エレベーター乗降ロビーの加圧給 気ファンを起動するとともに，中廊下の圧力調整ガラリを開放し， 中廊下と付室を一体の空間として加圧する。非常用エレベーター 乗降ロビーと付室の天井裏に設置された常時開放のバイパス開口 を介して，中廊下一新鮮空気を供給する。同時に乗用エレベータ ーシャフトの給気ファンを起動し，乗用エレベーターシャフトと 中廊下間で遮煙を行う。各住戸と中廊下間は，常時閉鎖式の防火 設備で区画し，中廊下への火煙の扡大を抑制する。

B. 漏煙モード：出火住戸より中廊下に漏煙した場合は，中廊下の 
煙感知器に連動して付室の防火戸（上部）が閉鎖するとともに, 廊下の機械排煙設備を起動して，付室と中廊下間，乗用エレベー ターシャフトと中廊下間で遮煙を行い，非火災階への煙伝播を防 止する。非常用エレベーター乗降ロビーと付室は, 天井裏に設置 された常時開放のバイパス開口を介して，一体の加圧空間となる。

万が一，中廊下の排煙設備が作動しない場合は，中廊下の圧力 調整ガラリにより，外気への排気経路を確保し，付室と中廊下間， 乗用エレベーターシャフトと中廊下間で遮煙を行う。

\section{4. 設計段階における火災シナリオの設定}

\section{1 システムの作動モードに関するシナリオ}

設計段階では，システムの作動条件の観点から，以下に示す火災 シナリオを想定し，一層ソーンモデルにより避難安全性評価を実施 した。シナリオ毎の扉開閉条件，煙制御条件を表 3 に示す。

\section{A. 通常モード}

火災時の避難に伴う避難経路上の屝の開閉条件を考慮し，通常モ 一ドとして，階避難中，階避難終了の 2 つのシナリオを設定した。

- 階避難中 : 出火階の非出火住戸の避難段階（シナリオ $\mathrm{A}-1$ )。

-階避難終了: 出火階の全住戸がらの避難終了段階（シナリオ A-2）。 B. 霃煙モード

当加圧防煙システムにおいて，システムが作動した状態で，中廊 下に高温の煙が伝播し，出火階の在館者が避難できなくなるのは， 以下の3つの条件が発生した場合と考えられる。

(1) 住戸内のスプリンクラーが有効に作動しない。

（2）出火した住戸と中廊下間の扉が避難に伴う障害物の影響で,

一部開放されている。

(3) 廊下の排煙設備が有効に機能しない。

以上の条件を考虑し，設計段階においては，漏煙モードとして， 以下に示す 3 つのケースを想定した。

・スプリンクラー不作動：住戸内のスプリンクラーが作動しない規

模の火災が発生し，廊下に煙が伝播した場合（シナリオ B-1）。 ・中廊下排煙作動：出火住戸が盛期火災に達して，中廊下に漏煙し，

排煙設備が作動した場合（シナリオB-2）。

-中廊下排煙不作動：出火住戸が盛期火災に達して, 中廊下に漏煙

し，中廊下の排煙設備が作動しなかった場合（シナリオB-3）。 漏煙モードでは，出火住戸の避難終了後，玄関扉に障害物が挟ま った状態を想定して，住戸扉を一部開放とした（有効開口率 $10 \%$ )。 また，万が一付室親扉が閉鎖しなかった場合を想定し，付室親屝を 開放とした。

4.2 火災条件、気象条件に関するシナリオ

気象条件，火災階，火源に関するシナリオの条件は，各々避難安 全上危険側となる条件を考虑し，以下の考えに基づき設定した。

\section{1）気象条件・火炎階}

エレベーターシャフト内の煙突効果を考慮し，夏期に 24 階の住戸 で出火した場合を想定した（初期温度 : 外気 $30^{\circ} \mathrm{C}$, 住戸・廊下・付 室 $26^{\circ} \mathrm{C}$, 階段室・エレベーターシャフト $28^{\circ} \mathrm{C}$ ] [注 2]。また, 外気 風の影響により，火災室から中廊下へ煙が伝播する危険性があるこ とから，シナリオ B-2, B-3 では，盛期火災に達し出火住戸の窓カラ スが温度上昇により破損した場合を考虑し，火災室外壁に対して正 圧となるように外気風（風速 $7.0 \mathrm{~m} / \mathrm{s}$ ）を設定した[注 3$]$ 。
表 3. 設計段階での想定条件とシステム起動・屝開閉シナリオ

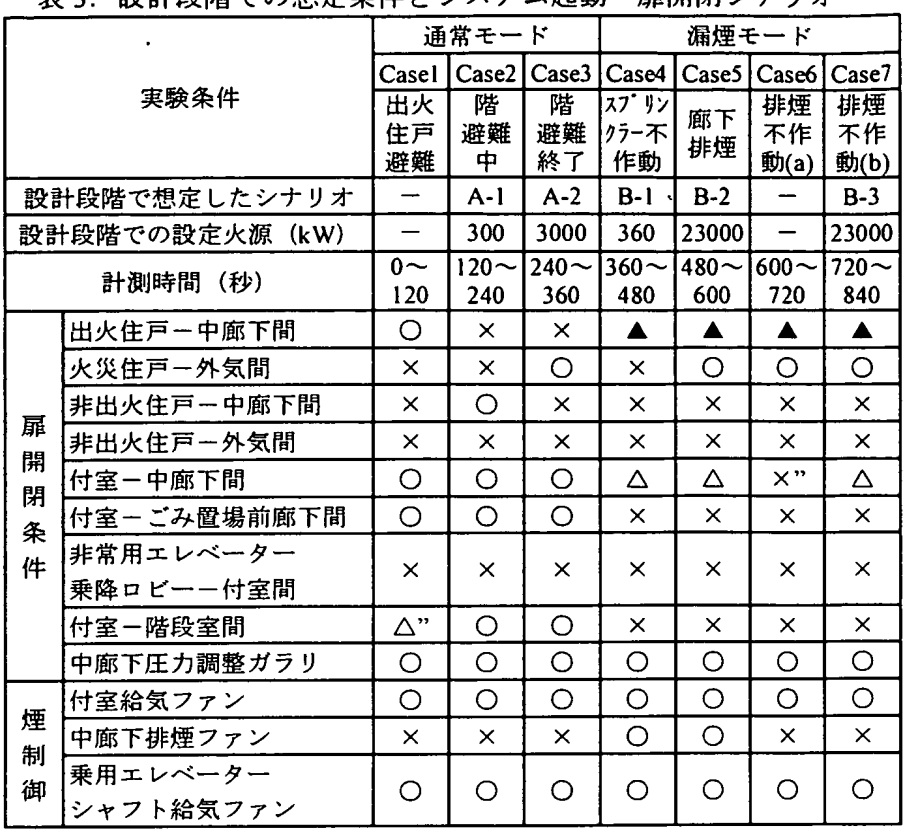

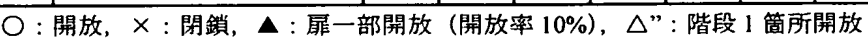

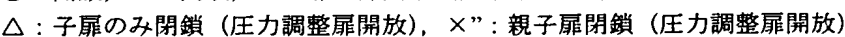

\section{2 ）火源の発熱速度}

火源の発熱速度は，想定したシナリオ毎での火災の進展状況を考 慮し，表 3 に示す值を用いた。スプリンクラー不作動（シナリオ B1）では，スプリンクラーが作動しない最大規模の発熱速度が継続 したものとして，住戸の天井高さ $(2.3 \mathrm{~m})$ ，火源とスプリンクラー ヘッドとの最大水平離隔距離 $(2.3 \mathrm{~m})$ を考虑して，発熱速度を設定 した[注 4]。盛期火災を想定したシナリオ（B-2，B-3）では，外壁に 面した開口が破損し，換気支配型の燃焼に達した場合を想定し，発 熱速度を設定した[注 5]。

\section{5. 性能確認実験の概要}

\section{1 実験の目的}

住宅階を対象として，設計段階で設定したシナリオに対して，䇋 工時に以下の性能が確保されていることを確認する。

1) 遮煙位置の室間圧力差が遮煙に必要な值以上であること。

2) 避難経路の扉開放力が，開閉に支障がない值以下であること。 5.2 実験条件

実験は，2000 年 7 月 22 日に実施した。当日の気象条件は，外気 温度約 $29^{\circ} \mathrm{C}$, 屋上階での風向・風速は, 南西約 $1.3 \mathrm{~m} / \mathrm{s}$ であった。

住宅階のうち 18 階を実験対象とし, 表 3 に示すケースを設定し て実験を行った。性能確認実験では, 設計段階での想定シナリオに 加え，通常モードとして，出火した住戸で避難を行っている場合 (Casel)，漏煙モードとして，付室親屝が正常に起動した場合の中 廊下排煙不作動（Case6）の場合の 2 ケースを追加した。

なお，漏煙モードでは，出火住戸の避難終了後，玄関郝に障害物 が挟まった状態を想定して，住戸扉を約 $10 \mathrm{~cm}$ 開放した。Case5〜7 では，出火住戸が盛期火災に達し，外壁空が破損した状態を想定し， 出火住戸の空を開放した。また，Case4，5，7 は，万が一付室の親屝 $(\mathrm{W}=1.35 \mathrm{~m})$ が閉鎖しなかった場合を想定して，子屝 $(\mathrm{W}=0.45 \mathrm{~m})$ のみを閉鎖した。 
付室加圧ファン, 乗用エレベーターシャフト加圧ファンは, 予め 起動した上で, 各ケース毎に 2 分間計測を行った。なお；図1の住 戸A を火災室として設定したが, 住戸内で火源を模擬した燃焼を行 うことが困難であったため，模擬的な火災の再現は行っていない。

\section{3 测定項目}

測定項目は, 室間の圧力差, 室内温度, 悲面風速, 給排気ダクト 風速，外気風速である。代表的な測定項目の測定点を図 1に示す。 各測定データは，2 秒間隔でデータロガーに取り込み記録した。

\section{6. 性能確認実験の結果と考察}

\section{1 システム作動モードに対する遮煙位置での窒間圧力差}

性能確認実験の結果得られた室間圧力差の時間変動を図 3 に示す。 なお，㥶験時の非常用エレベーター乗降ロビーの給気風量測定值は， 約 $15,000 \mathrm{~m}^{3} / \mathrm{h}$, 中廊下の排気風量測定値は, 約 $9,000 \mathrm{~m}^{3} / \mathrm{h}$ であった

(各 1 系統当たり)。

1) 通常モード

1-a) 出火住戸避難（Casel）

出火住戸の屝が開放されるため, 出火住戸の外壁空が閉鎖してい ると, 中廊下と住戸との圧力差は, ほぼ゙ロとなる。但し, 出火住 戸避難は，火災の初期段階であり，かつ韮の開放時間は短いと考え られることから，中廊下へ漏煙する危険性は低いと考えられる。

1-b) 階避難中 (Case2)

階避難中は，非火災住戸の在館者の避難が行われているが，火災
住戸の外壁空が閉鎖した状態においても，中廊下と出火住戸間との 圧力差は，約 5Pa を確保しており，中廊下八漏煙する危険性は低い。 1-c) 階避難終了（Case3）

階避難段階で火災住戸の外壁空を開放した場合でも，中廊下と火 災住戸間との圧力差は，約 7Pa であり，中廊下へ漏煙する危険性は 低い。

今回の実験では，火災室として想定した住戸が風上側（南側）に 位置していたが，図 3(1)，(2)より，通常モードでは，出火住戸を介 した中廊下ー外気間の圧力差は，外壁空の開閉状態に関わらず，約 7Pa を確保しており，火災室の屝が長時間開放されない限り，火災 室から中廊下に漏煙する危険性は低いと考えられる。また，Case1 〜3 を通じて, 乗用エレベーターシャフトと中廊下間の圧力差は, 約 5〜8Pa を確保しており，エレベーターシャフトを介して，非火 災階一漏煙する危険性は低い。

2) 漏煙モード

2-a) スプリンクラー不作動, 中廊下排煙作動（Case4, 5)

中廊下排煙が起動し，万が一付室親屝が 1 枚開放されたままの状 態の場合, 遮煙位置である付室扉での圧力差は約 $0.6 \mathrm{~Pa}$, 扉開放時 の扉面での平均風速は約 $0.8 \mathrm{~m} / \mathrm{s}$ となっている。設計段階で一層ソー ンモデルにより中廊下の煙温度を予測した結果, Case4 で約 $27^{\circ} \mathrm{C}$, Case5 で約 $34^{\circ} \mathrm{C}$ となり, 遮煙に必要な圧力差は $0.6 \mathrm{~Pa}$ となる。以上 より，中廊下に漏煙し，かつ付室親屝が 1 枚開放された場合でも， 遮煙に必要な圧力差は確保されている。

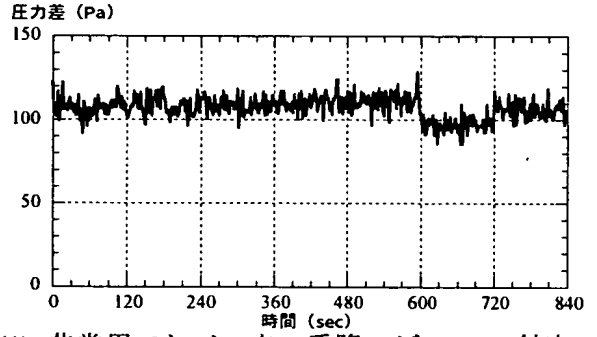

(1) 非常用エレベーター乗降ロビー(+)ー付室(-) 間 : P1
表 4. 加圧防煙システム起動時の必要屝開放力

\begin{tabular}{|c|c|c|c|}
\hline & 住灭屝 & 付室親屝 & $\begin{array}{c}\text { 非常用エレペータ- } \\
\text { 乗降吡一扉 }\end{array}$ \\
\hline システム未起動時の扉開放力 $F_{0}(\mathrm{~N})$ & 41 & 25 & 16 \\
\hline 翡幅 W(m) & 0.9 & 1.35 & 0.8 \\
\hline 罪高さ $H(m)$ & 2.1 & 2.0 & 2.1 \\
\hline 加圧時の最大圧力差 $\triangle \mathrm{P}(\mathrm{Pa})$ & $6.9(16.2)$ & 17.1 & 111.4 \\
\hline 扉開放に必要な力 $\mathrm{F}(\mathrm{N})$ & $47.5(56.3)$ & 48.1 & 109.6 \\
\hline
\end{tabular}

*加圧時の最大圧力差は，出火住戸の測定值を示す。但し，同欄の括弧内の数值は， 廊下排煙不作動時の非出火住戸（測定点 P13）の值を示す。

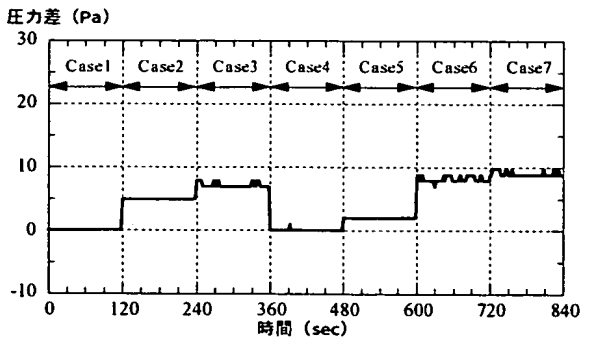

(2) 中廊下 $(+)$-出火住戸 $(-)$ 間 : P11

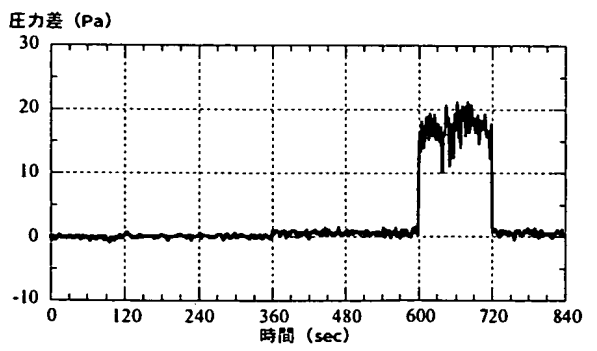

(5) 付室(+)-中廊下(-) 間 : P3

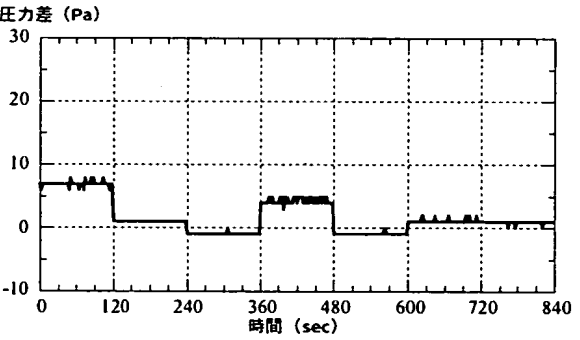

(3) 出火住戸 $(+)$-外気(-) 間 : P16

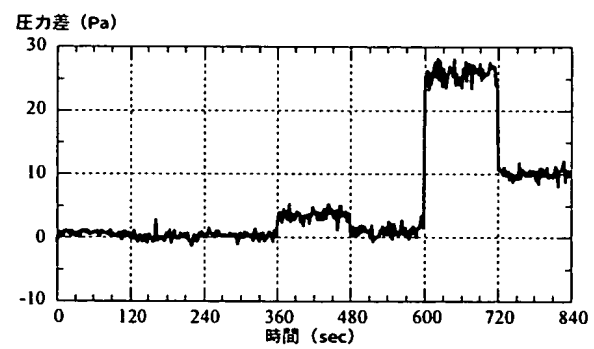

(6) 付室(+)一階段室(-) 間 : P5

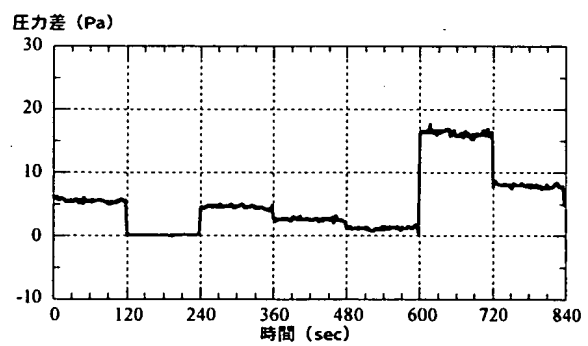

(4) ごみ㯰場前廊下 $(+)$ 一非出火住戸(-) 間 : P13

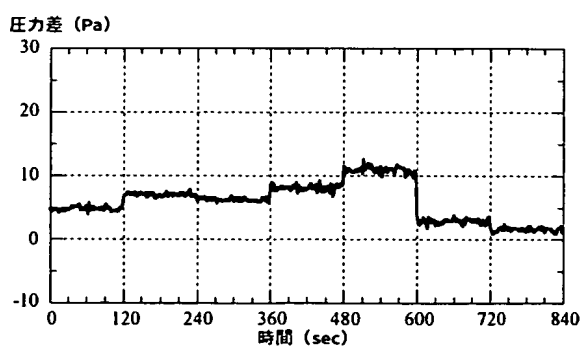

(7) 乗用 ELV シャフト (+)ー中廊下(-) 間 : P14

図 3. システム作動モードに対する圧力差の時間変化 
2-b) 中廊下排煙不作動 (Case6, 7)

中廊下の排煙機が作動せず，かつ付室親屝が 1 枚開放された場合， 遮煙位固である付室一中廊下間の圧力差は約 $0.6 \mathrm{~Pa}$ となっている。 また，付室親屝が正常に閉鎖した場合は，付室一中廊下間で約 $17 \mathrm{~Pa}$ 確保されている。設計段階で行なった中廊下の煙層温度の予測結果 は，Case7 では約 $26^{\circ} \mathrm{C}$ であり，ほとんど温度上昇がみられないこと から，中廊下に漏煙し，付室扉が 1 枚開放された場合でも，遮煙に 必要な圧力差は確保されていると考えられる。

Case4〜7 を通じて，乗用ェレベーターシャフトと中廊下間の圧力 差は, 約 2〜11Pa を確保している。設計段階での煙層の温度予測結

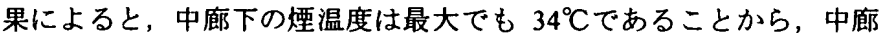
下を介して非火災階一漏煙する危険性は低い。

消防活動拠点の観点からは，付室と非常用エレベーター乗降ロビ 一は平面上分割されており，中廊下に対して二重の防火戸で隔てら れていること，また非常用エレベーター乗降ロビーの扉が閉鎖され ていれば，付室扉の開閉条件に関わらず，非常用エレベーター乗降 ロビーと付室の間で最低でも約 97Pa を確保していることから，火 災が拡大し，中廊下に漏煙した場合でも，充分な防煙性能を有して いると考えられる。

\section{2 システム起動時の丞必要開放力}

一般に住宅では，就寝時等に避難開始が遅れる可能性があること， 高齢者や児童等が居住することから，加圧防煙システム起動時に屝 開閉に障害が生じないことは，避難安全上重要となる。システム起 動時に開閉障害の生じる可能性がある住戸扉と付室親扉を対象とし て，扉必要開放力を算出した。システムを起動しない状態で屝開放 力を予め測定した上で，性能確認試験における圧力差の測定結果を 用いて，(1)式によりシステム起動時の扉必要開放力(F) を算出した。

$$
F=F_{0}+\frac{1}{2} W H \Delta P
$$

ここで， $\mathrm{F}_{0}$ はシステム未起動時の扉開放力 $(\mathrm{N}), \mathrm{W}$ は屝幅 $(\mathrm{m})$ $\mathrm{H}$ は屝高さ $(\mathrm{m}), \triangle \mathrm{P}$ は加圧時の床面での最大圧力差 $(\mathrm{Pa})$ を示す。

必要扉開放力の算出結果を表 4 に示す。住戸，中廊下，付室に設 置した圧力調整機構により，システム起動時の扉必要開放力は，住 戸屝，付室親郝ともあまり違いはなく，最大で $56.3 \mathrm{~N}$ に収まってい る。成人の屝開放力は，約 100〜200N といわれており "，システム 起動時に成人が罪を開閉するのに，避難上特に問題はないと考えら れる。一方，既往の研究 ${ }^{2)}$ によると，小学校 3 年から 6 年生の児童 の扉開放扉開放力は，片手で屝を押した場合，男子で約 60〜220N， 女子で約 50〜160N であり，女子が両手で屝を押した場合の扉開放 力は約 75〜200N となっている。以上より，女子児童が住戸内に単 独で取り残された場合，片手で屝を開閉するのには一部障害の生じ る可能性は残るが，屝開閉上概ね問題はないと考えられる。

非常用エレベータ一乗降ロビーの屝は，加圧時の必要扉開放力が

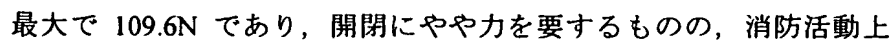
特に問題はないと考えられる。

\section{7. 住宅階の建物部位の嗦間有効開口面積の測定}

住宅階の主な建物部位の隙間有効開口面積を把握するため, 2000 年 8 月 9 日に, 18 階を対象として測定を行った。気象条件は，外気 温度約 $30^{\circ} \mathrm{C}$, 屋上階での風向・風速は, 南東約 $3.2 \mathrm{~m} / \mathrm{s}$ であった。

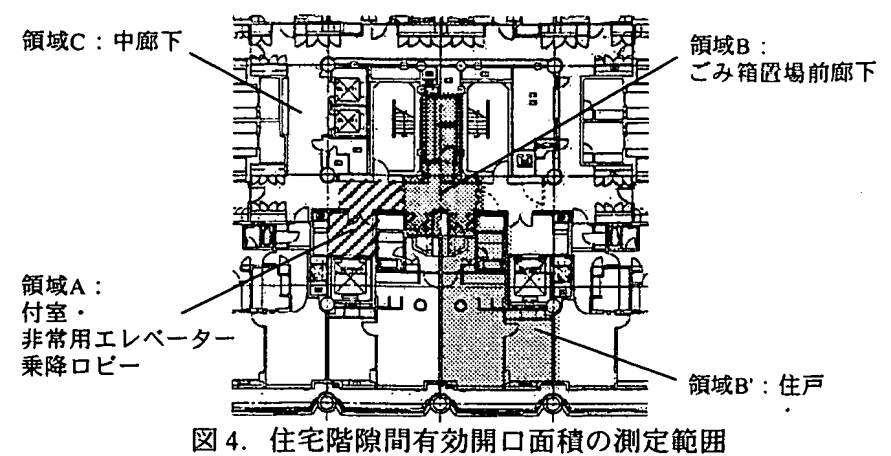

表 5. 建物部位別の隙間有効開口面積の測定結果

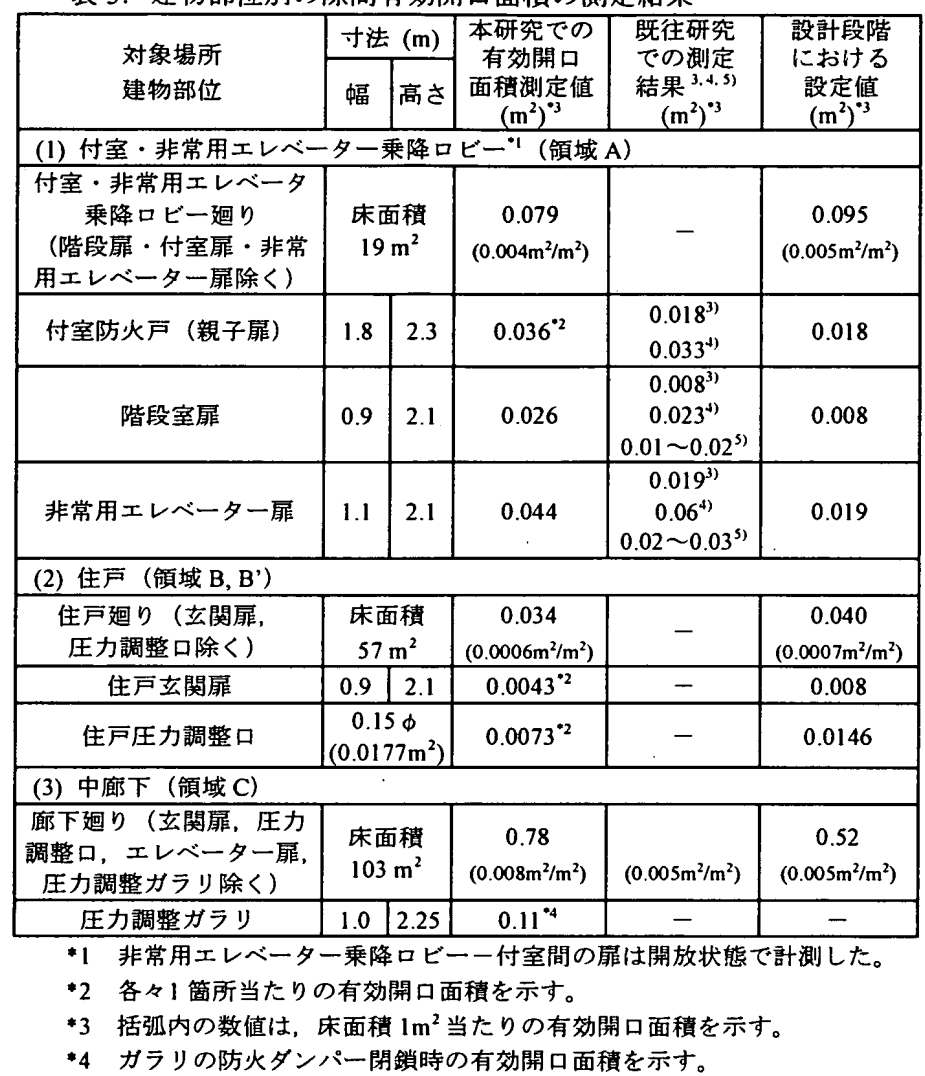

\section{1 測定対象部位と測定方法}

（1）付室・非常用エレベーター乗降ロビー，(2) 住戸，(3) 中廊下 において，表 5に示す部位を対象として測定を行なった。

1）付室・非常用エレベーター乗降ロビー（領域 A）

図 4 の領域 A を対象とし，周辺の啡に全て目貼りをした状態で, 加圧給気ファンを起動して, 付室と中廊下間の圧力差, 給気風量, 付室内温度を測定した。その後付室扉, 階段室扉, 非常用エレベー ター郝の順で目貼りを除去し，各々 30 秒問測定を行なった。非常用 エレベーター乗降ロビーー付室間の扉は常時開放とした。中廊下を 外気に近い圧力に保つため, 18 階の全住戸の玄関屝・外気側空, 及 び測定対象でない側の階段室屝は常時開放とした。

2) 住戸(領域 B, B')

付室一ごみ箱直場前廊下間の扉を開放し，図 4 の領域 A と B を一 体の加圧空間として，2 住戸分の中廊下一住戸間圧力逃し口，住戸 屝に目貼りをした状態で，付室の加圧給気ファンを起動して，付室 と中廊下間の圧力差, 給気風量, 付室内温度を測定した。その後, 圧力調整口，住戸屝の順で目貼りを除去し，30 秒間隔で測定を行な 
った。測定終了後, 領域 B'の住戸玄関扉を開放し，外気側空を閉鎖 した状態で，領域 B'について同様の測定を行なった。なお、ごみ箱 直場前廊下の換気口，住戸の郵便受けは，常時目貼りし，住戸内の 換気扇は閉鎖状態とした。また，中廊下迴りの開口条件は，1)と同 棣とした。

3) 中廊下 (領域 C)

図 4 の領域 C を対象とし，乗用エレベータ一㞸，圧力調整ガラリ に目貼りした状態で，廊下の排煙ファンを起動し，廊下一付室間の 圧力差, 排煙風量, 廊下内温度を測定した。18 階の全住戸の玄関扉 と付室屝は閉鎖し，全住戸の外気側窓と階段室屝は常時開放とした。 上記 1) 3)の測定データの 30 秒間の平均值を用いて，(2)式によ り，建物部位毎の隙間有効開口面積を算出した。

$$
\alpha A=q / \sqrt{2 \Delta P / \rho}
$$

ここで， $\alpha \mathrm{A}$ は各部位毎の隙間有効開口面積 $\left(\mathrm{m}^{2}\right), \mathrm{q}$ は給気（排 気）風量 $\left(\mathrm{m}^{3} / \mathrm{s}\right), \triangle \mathrm{P}$ は付室一廊下間の圧力差 $(\mathrm{Pa}), \rho$ は空気の密 度 $\left(\mathrm{kg} / \mathrm{m}^{3}\right)$ を示す。

\section{2 測定結果}

建物部位毎の隙間有効開口面積の算出結果を表 5 に示す。

1) 付室・非常用エレベーター乗降ロビー（領域 A）

表 5 より，階段室扉，付室防火戸，エレベーター扉は，既往の研 究 (例えば ${ }^{3)}$,4). 5) $)$ における測定結果とほぼ同様の值となっている。

付室・非常用エレベーター乗降ロビ一奋りの隙間は，床スラブと 壁間等が考えられる。付室の間仕切り壁は，乾式工法を採用してお り，躯体部分に両開きの防火戸約 2 枚分の隙間があることがわかる。

2 ) 住戸(領域 B, B')

住戸迴りの隙間面積は，玄関屝と圧力調整口の隙間面積の合計 $\left(0.0116 \mathrm{~m}^{2}\right)$ の約 3 倍となっている。住戸迴りの隙間の要因としては, 外壁公サッシュ，換気口，壁・スラブ接合部等が考えられる。

圧力調整口の有効開口率 $(\alpha)$ は, $0.41 \quad\left(=0.0073 \mathrm{~m}^{2} / 0.0177 \mathrm{~m}^{2}\right)$ となる。圧力調整口は，丸管の両端に同一径のエルボーが設置され ており，エルボーの抵抗が有效開口率に影響していると思われる。

3) 中廊下 (領域 C)

単位床面積当たりの隙間面積は， $0.008 \mathrm{~m}^{2} / \mathrm{m}^{2}$ であり，事務所ビル の中廊下を対象とした既往の測定結果 ${ }^{3)}$ と比較すると約 5 割大きく なっている。集合住宅は，中廊下周辺に排水口等の設備配管が敷設 されており,スラブと配管との接合部等が隙間を生じる主要な要因 として考えられる。

中廊下の圧力調整カララリ（開口率 80\%）は，羽根式のダンパーで 閉鎖する機構となっている。ダンパー閉鎖時のガラリ面積に対する 有効開口率 $(\alpha)$ は，約 0.05 となった。

\section{8.おわりに}

本報では，高層集合住宅における加圧防煙システムの適用事例と その性能確認実験および建物部位の隙間有効面積の実測結果につい て述べた。本研究の結果を整理すると以下のようになる。

・集合住宅階での火災の進展や避難行動に伴い想定される各シナリ オに対して，当該加圧防煙システムは、圧力制御による遮煙性能 を満足している。

・集合住宅の用途特性上, 在館者として想定される高龉者や児童の
避難に対して，本システムで導入した圧力調整機構は，避難経路 の加圧に伴い発生する屝開閉障害を防止する効果を有する。

・集合住宅では中廊下迴りの躯体の単位床面積当たりの隙間有效開 口面積は，事務所の廊下と比較すると約 5 割大きい。住戸扉の圧 力調整用開口の有効開口率は約 0.4 であった。階段室，付室等の 屝は，既往の測定値とほほ同じ值であった。

本報で報告した建物は，一般的な高層集合住宅への加圧防煙シス テムの適用という観点からすると， 全館スプリンクラー設㯰や 24 時間有人管理など，防火対策や維持管理面で，事務所との複合用途 であることによる特殊性があることは否めないが，こうした条件が 揃えは，従来の集合住宅と比較して，中廊下型の避難経路を長時間 安全に確保できるため, 避難安全性を向上できる解決策のひとつと して，当該システムは有効であると考えられる。

最後に，当実験の実施に当たり，ご協力をいただいた関係各位に 心より謝意を表します。

[注 1] 集合住宅単独用途の高層建物では，維持管理の実態調查の結果 のににみ られるように，一般的に，24 時間有人管理を行っている事例は少なく，夜 間は無人管理となることが多い。

[注 2] 煙流動の予測に際し，对象空間は，想定火災階（24 階）の主要な室（住 戸，中廊下，付室），火災階に面する竪穴空間（乗用・非常用エレベーター シャフト，階段室，中廊下圧力調整タクト）を対象としてモテルル化し，室 間の開口条件は，ケース毎の扉開閉条件を考磨して設定した。扉開鎖時の 隙間開口は，表 5 の「設計段階での設定值」を使用した。

[注 3] 対象とする建物は，全方位に住戸の外壁空が面することから，東京管

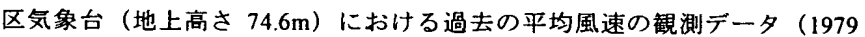
年 3 月〜1983 年 2 月) "をもとに, 発生確率の最も高い風向 (NNW) にお ける平均風速の超過確率が $5 \%$ となる風速を求め, 外気風速を設定した。 風速の発生頻度分布としてワイブル分布を仮定した上で，对象建物の屋上 階床面の地上高さ $(95.4 \mathrm{~m})$ における平均風速の超過確率が $5 \%$ となる風速

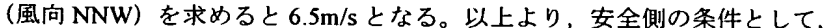
外気風速の設定值 $(\mathrm{V})$ を $7.0 \mathrm{~m} / \mathrm{s}$ とした。

[注 4] スプリンクラーが作動しない最大規模の発熱速度（ $\left.\mathrm{Q}_{s}\right)$ は, 以下の式 により算出した ${ }^{81}$ 。

$$
Q_{s}=0.08 r\left\{\left(T_{C}-T_{0}+\Delta T\right) H\right\}^{3 / 2}
$$

ここで, $\mathrm{r}$ : 火源の気流中心軸とスプリンクラーヘッドとの水平距離 $(=2.3 \mathrm{~m})$, $\mathrm{T}_{\mathrm{c}}$ : スプリンクラーヘッドの公称作動温度 $(=345 \mathrm{~K}), \mathrm{T}_{0}$ : 㷅囲気温度 $(=299 \mathrm{~K})$, $\Delta T:$ 余裕温度 $(=20 \mathrm{~K}), \mathrm{H}$ : 天井高さ $(=2.3 \mathrm{~m})$ を示す。

[注 5] 火災室が盛期火災に達し，換気支配型燃焼に至った段階での火災室の 発熱速度 $\left(\mathrm{Q}_{\mathrm{D}}\right)$ は，以下の式により算出した。 $Q_{D}=1500 A \sqrt{H}$

ここで, A : 外壁に面する開口面槽 $\left(=10 \mathrm{~m}^{2}\right), \mathrm{H}$ : 開口高 $(=2.0 \mathrm{~m})$ を示す。

\section{参考文献}

1) 建設省住宅局建築指導課監修：新・排煙設備技術指針 1987 年版, 日本建 築センター, p.183，1987

2) 佐藤和子：男女児童のドアの開角度と開屝力について, 日本建築学会大会 学術䛾演梗概集 (北陸), No.5325, 1983.9

3）措川秀史, 矢代嘉郎, 広田正之, 石川雅之, 中村健 : 実証試験に基つく加 圧防煙システムの計画手法の検証，清水建設研究報告，第 55 号，1992

4) 笠原熟, 中濱慎司, 硧渡潔, 池畠由華 : 特別避難階段付室の除間開口面積, 日本建築学会大会学術講演梗概集（関東）， No.3065，2001.9

5）建設省大臣官房技術調查室：建案物の総合防火設計法 第 1 巻 総合防火設 計法, p.56, 1989

6）宮野義康，長谷見雄二：高層共同住宅における防火管理の実態調査，日本 建築学会大会学術譵演梗概集 (関東)，No.3106，2001.9

7) 風工学研究所編 : 新・ビル風の知躘，鹿島出版会，pp.38〜39，1989

8) 建設省大臣官房技術調查室監修: 建築物の総合防火設計法 第 3 巻 避難安 全設計法，日本建築センター，p.90，1989

[2001年10月19日原稿受理 2002年 2 月18日採用決定］ 